\title{
Advances in corporate brand, corporate heritage, corporate identity and corporate marketing scholarship.
}

\author{
John M.T. Balmer \\ The Marketing and Corporate Brand Research Group, Brunel University Business \\ School, Brunel University London, UK. \\ Email: john.balmer@brunel.ac.uk
}

\begin{abstract}
Purpose - Introduces the special symposium entitled "Advances in corporate brand, corporate heritage, corporate identity and corporate marketing scholarship" and provides a synopsis of the five articles constituting this symposium. By means of context, celebrates the anniversaries of four marketing milestones apropos the formal introduction of the corporate brand concept (1995), the formal introduction of the corporate heritage notion (2006), the first special edition (in this journal) devoted to corporate identity (1997) and the formal introduction of the corporate marketing philosophical approach (1998). The latter - corporate marketing can be viewed as a revolution in marketing thought by noting that mutually beneficial company-stakeholder relationship can be based on corporate identities and corporate brands are not restricted to products and/or services.

Design/Methodology/Approach - Taking a retrospective, explains the above four critical milestones and the corporate marketing revolution which have meaningfully advances marketing scholarship for the past 20 years.

Findings - Provides 18 reflections of developments with the corporate brand and corporate identity fields. Also shows the seminal importance of EJM special editions on the territory dating back to 1997.

Originality/value - In marking these milestones, this celebratory European Journal of Marketing (EJM) symposium comprises cutting-edge scholarship on the aforementioned areas, penned by renowned and prominent scholars from Australia, England, Germany and the USA.

Practical implications- Discusses how corporate identity, corporate branding, corporate heritage, corporate identity and corporate marketing have, increasingly, become mainstream marketing concerns.

Keywords - Corporate brand, Corporate heritage, Corporate identity, Corporate marketing

Paper type - Guest editorial and commentary
\end{abstract}




\section{Introduction and Article Structure}

The timing and foci of this symposium is propitious. It is also auspicious since it marks several, critical, milestones in the annals of corporate marketing research and scholarship apropos corporate identity, corporate brand, corporate heritage and corporate marketing scholarship.

In marking these milestones, this celebratory European Journal of Marketing (EJM) symposium comprises cutting-edge scholarship on the aforementioned areas, penned by renowned and prominent scholars from Australia, England, Germany and the USA.

Let me now continues by delineating these critical mileposts; briefly detail some of the key advances in these fields, note the foci of EJM special editions on the broad corporate marketing areas since 1997, and, finally, provide an overview of the five articles constituting this celebratory symposium.

\section{Celebrating four milestones and one revolution}

What, precisely, are the four critical milestones and what is the marketing revolution mentioned above?

1st milestone: the European Journal of Marketing Special Edition on Corporate identity (Balmer and Van Riel 1997)

The first critical milestone commemorates and celebrates the twentieth anniversary of the ground-breaking European Journal of Marketing (EJM) special edition devoted to corporate identity. This was guest edited by John M.T. Balmer and by the celebrated Dutch corporate communications scholar Professor C.B.M. Van Riel (Balmer and Van Riel, 1997). This special edition was highly significant since it is understood to be the first special edition of its kind: the first special edition devoted to corporate identity. As such, the special edition made a considerable impact since it underscored the importance of corporate identity as a mainstream marketing scholarly concern. Until this special edition, a good deal of the writing on the area had been penned by practitioners. Today, the situation has been reversed. As such, this symposium celebrates the $20^{\text {th }}$ anniversary of this EJM special edition devoted to corporate identity (1997-2007): see, in particular, the article on corporate identity by Balmer (2017) in this EJM symposium.

\section{$2^{\text {nd }}$ milestone: the formal introduction and initial explication of the corporate brand notion (1995)}

The second milestone comes in the wake of another momentous development: the formal introduction of the corporate brand notion in 1995. This appeared in the Journal of General Management and was entitled: "Corporate branding and connoisseurship" (Balmer, 1995). In the 1990 s and early 2000 s there was considerable bemusement apropos the corporate brand notion. Twenty years on, in good part because of the perseverance of English and other scholars from the mid-1990s onwards, the corporate brand notion has, today, entered this mainstream. Notably, whereas the corporate identity field had been popularised by practitioners, marketing scholars took the lead in introducing and advancing the corporate branding field. This symposium, in part, celebrates the $20^{\text {th }}$ anniversary of the formal introduction of the corporate brand notion (1995-2005): see, in particular, the articles by Schroeder (2017) and Brexendorf and Keller, (2017) on corporate brands in this EJM symposium .

$3^{\text {rd }}$ milestone: the formal introduction and initial explication of the corporate heritage notion.

The third milestone is the formal introduction of the corporate heritage brand notion in 2006 (Balmer, Greyser and Urde, 2016) and the subsequent elaboration of the corporate heritage brand notion (Urde, Greyser and Balmer, 2007). The formal identification of a distinct genus of corporate identity/corporate brand identity has 
resulted in an exponential growth of interest in the broad corporate heritage area: the interest will almost certainly continue and is likely to gain pace over the next years. This symposium, in part, celebrates the $10^{\text {th }}$ anniversary of the above (2006-2016): see, in particular, the article by Balmer and Chen (2017) on corporate heritage brands in this EJM symposium .

$4^{\text {th }}$ milestone and a marketing revolution: the formal introduction of the corporate marketing notion (1998)

Looking ahead, we are on the cusp of not only another milestone but also the anniversary of, arguably, a revolution in marketing: the initial introduction and exposition of the corporate marketing notion (Balmer, 1998). Almost twenty years ago the following statement was made:

"Recent developments have led the writer to postulate that the literature on corporate identity, organisational identity and corporate communication may be regarded as forming the basic building blocks of a new, cognate area of management which in time may be known as Corporate Marketing."

(Balmer, 1998. p.963)

In retrospect, the formal introduction of the corporate marketing notion (Balmer, 1998 ) is not only a milestone but may been seen to be a marketing revolution. See Balmer and Greyser, (2006) for an overview of the antecedents and characteristics of corporate marketing. This is because a corporate marketing philosophy focusses on organisations, corporate-level constructs, CSR/Ethics, Omni-temporality and company-customer and key stakeholder relationships (Balmer, 2011). Traditionally, mutually beneficial exchange relationships in marketing apropos organisations and customers focussed on products, services and their attendant brands. In contrast, corporate marketing, focuses on mutually beneficial exchange relationships between organisations and stakeholders focussed on corporate identities and corporate brands. Importantly, this renaissance of marketing thought/philosophy complements both the traditional marketing, and relationship marketing orientations (Balmer and Greyser, 2006 p. 732). See fig 1 below. This symposium, in part, celebrates the $20^{\text {th }}$ anniversary of corporate marketing (19982008): see, in particular, the article by Leitch (2017) in this EJM symposium .

\begin{tabular}{|l|l|l|l|l|l|}
\hline \multicolumn{6}{|c|}{ Fig. 1 The Corporate Marketing Model and Philosophy } \\
\hline $\begin{array}{l}\text { Assumptions } \\
\text { about: }\end{array}$ & $\begin{array}{l}\text { Power balance } \\
\text { in the } \\
\text { marketplace }\end{array}$ & $\begin{array}{l}\text { Origin of needs } \\
\text { and desires }\end{array}$ & $\begin{array}{l}\text { Type of } \\
\text { power }\end{array}$ & $\begin{array}{l}\text { Marketplace } \\
\text { warning }\end{array}$ & Role of marketer \\
\hline & & & \multicolumn{2}{|l|}{} & \\
\hline & $\begin{array}{l}\text { Consumers } \\
\text { and } \\
\text { stakeholders } \\
\text { dominate }\end{array}$ & $\begin{array}{l}\text { With } \\
\text { consumers } \\
\text { and } \\
\text { stakeholders }\end{array}$ & $\begin{array}{l}\text { Consumer } \\
\text { and } \\
\text { stakeholder } \\
\text { sovereignty }\end{array}$ & $\begin{array}{l}\text { Caveat Societas } \\
\text { (company beware) }\end{array}$ & $\begin{array}{l}\text { To work with consumer } \\
\text { and stakeholders as the } \\
\text { servant of consumers and } \\
\text { stakeholders }\end{array}$ \\
\hline
\end{tabular}

Adapted from Balmer and Greyser (2006 p.733)

Reflections on corporate brand, and corporate identity, scholarship from 1995 to the present 
In reflecting on the above, the author makes the following 18 reflections (one or two pertain to corporate marketing and corporate heritage). See Fig 2 which shows a visual representation of the 18 reflections.

1. Centrality: increasingly scholars are waking up to the observations made in the 1990 s that corporate brands and corporate identities are deemed to be of central importance to organisations and stakeholders. In particular, the upsurge of interest in corporate brands corresponds to the notion that they can be standalone strategic assets. Moreover, corporate brands and corporate identities (and other corporate-level constructs) are increasingly viewed as being central to marketing. (This was certainly not the case in the 1990 s and early 2000 s where, among some, there was a widespread disinterest in corporate-level concerns in marketing. Arguably, the special editions of the EJM in the 1990 s and early 2000's were highly meaningful in creating awareness and interest in the above).

2. Corporate Brand Hierarchy: progressively scholars are according renewed attention to corporate brand hierarchies. This comes with a realisation that corporate brand hierarchies are fundamentally different from product-based varients. Significant work was undertaken in this area in the early 2000's in the UK.

3. Emotionality: occasionally, authors make the important distinction apropos the legal ownership of corporate brands and identities (vis-a vis organisations and shareholders) and emotional ownership of corporate brands and identities (in relation to customers and other shareholders)

4. Ethics and Social Responsibility: there is increased interest in ethical/CSR corporate brands and ethical identities from both organisational and stakeholder perspectives and a distinct literature has developed on these areas over the last decade or so.

5. Interdisciplinary: both the corporate brand and corporate identity fields stress/acknowledge the efficacy of multi-disciplinary perspectives. The multidisciplinary nature of the above areas was stressed during the 1990s. It has been more marked and accepted in recent times.

6. Legal theory: often overlooked, the legal theory of companies and its impacts on corporate identity, corporate identity traits and its management in particular is slowly being accorded importance. A company's articles of associations/charters etc. often stipulate an organisations identity traits and senior managers are legally obliged to adhere to the aforementioned.

7. Memory: an on-going characteristic and tension of the field is for scholars to ignore (and sometimes studiously ignore) and discount the foundational literatures. This can result in narrow conceptualisations, false attributions and an undermining the contributions within marketing, a privileging of North American and organisational behaviour contributions and a denying of European/Commonwealth etc. insights and scholarly advances.

8. Philosophy: increasingly both the corporate brand and corporate identity notions are viewed through a corporate marketing philosophy which has an explicit stakeholder, CSR/ethical, Omni-temporal etc. characteristics. Slowly, marketing scholars appreciate that not only products and services and their attendant brands can be bases for exchange relationships but also organisations and corporate brands too.

9. Ontology: the nature of corporate identity and of corporate brands has always been informed by diverse perspectives. These add richness but also complexity to the territory. However, disagreements apropos different perspectives can result in 
un-diplomatic and ill-conceived narratives which sometimes appear to reflect a visceral dislike of certain disciplines (including marketing). This is most regrettable.

10. Patrimony: increasing interest is being afford to corporate heritage organisations and corporate heritage brands/corporate heritage identities. This has come with a growing interest in issues of temporality and in particular in scholarly perspectives on the past. In particular, issues of organisational legacy, inheritance and provenance are seen to be germane.

11. Responsibility: particularly evident over recent years has been the realisation that everyone in an organisation has a responsibility/impact for the organisation's corporate brand and corporate identity. Again, such perspectives were evident in the literature in the 1990 s.

12. Sensory: again, from the 1990 s onwards, the importance of taking cognisance of all the senses (and not just the visual) was stressed and, recently, there has been a much-belated rival of interest in the aforementioned.

13. Social identity: this theory has been applied to both corporate identity and corporate branding areas and is seen to be highly significant apropos customers, employees and other key stakeholders. Arguably, this has been one of the leading theories in use in the broad corporate marketing field. Importantly, social identity theory provides a useful bridge between the corporate marketing and organisational behaviour disciplines.

14. Strategy: from the outset the foundational literatures on corporate brands and identity in the 1990s has emphasised their strategic nature and this dimension has recently been revisited.

15. Taxonomy: increasingly marketing scholars are cognisant with core corporate marketing concepts and their relationships (corporate brand, corporate identity, corporate communications, corporate image, corporate reputation, customer identification, stakeholder identification). Many of these constructs were already evident in the late 1990s. Significantly too, they are also likely to be familiar with key concepts from organisational behaviour and their relationships with the above (organisational identity, organisational identification and organisational images). Having cognisance of the above repertoire of concepts is a sine qua non for corporate marketing scholars.

16. Temporality: time is progressively viewed as an important dimension of corporate brands and identities. This is especially true of the past apropos corporate heritage. The Omni-temporality notion is also a key facet of a corporate marketing philosophy and has come with a realisation that the marketing philosophy (particularly corporate marketing) can be meaningfully informed not only by the present and future but also the past.

17. Supervisory: from the outset both areas were seen to fall within the stewardship of senior managers and this is increasingly recognised. Sometimes, the role of senior managers apropos corporate identity and corporate brands is ignored or they are assigned the role of by-standers in some of the recent literature.

18. Universality: twenty years on there is global organisational and stakeholder interest in corporate brands and corporate identity. This is especially evident in countries such as China and India. Moreover, there is universality in terms of scholarship. This is one of the most significant and important developments over recent years.

FIG 2. Reflections on corporate brand, and corporate identity, scholarship from 1995 to the present 


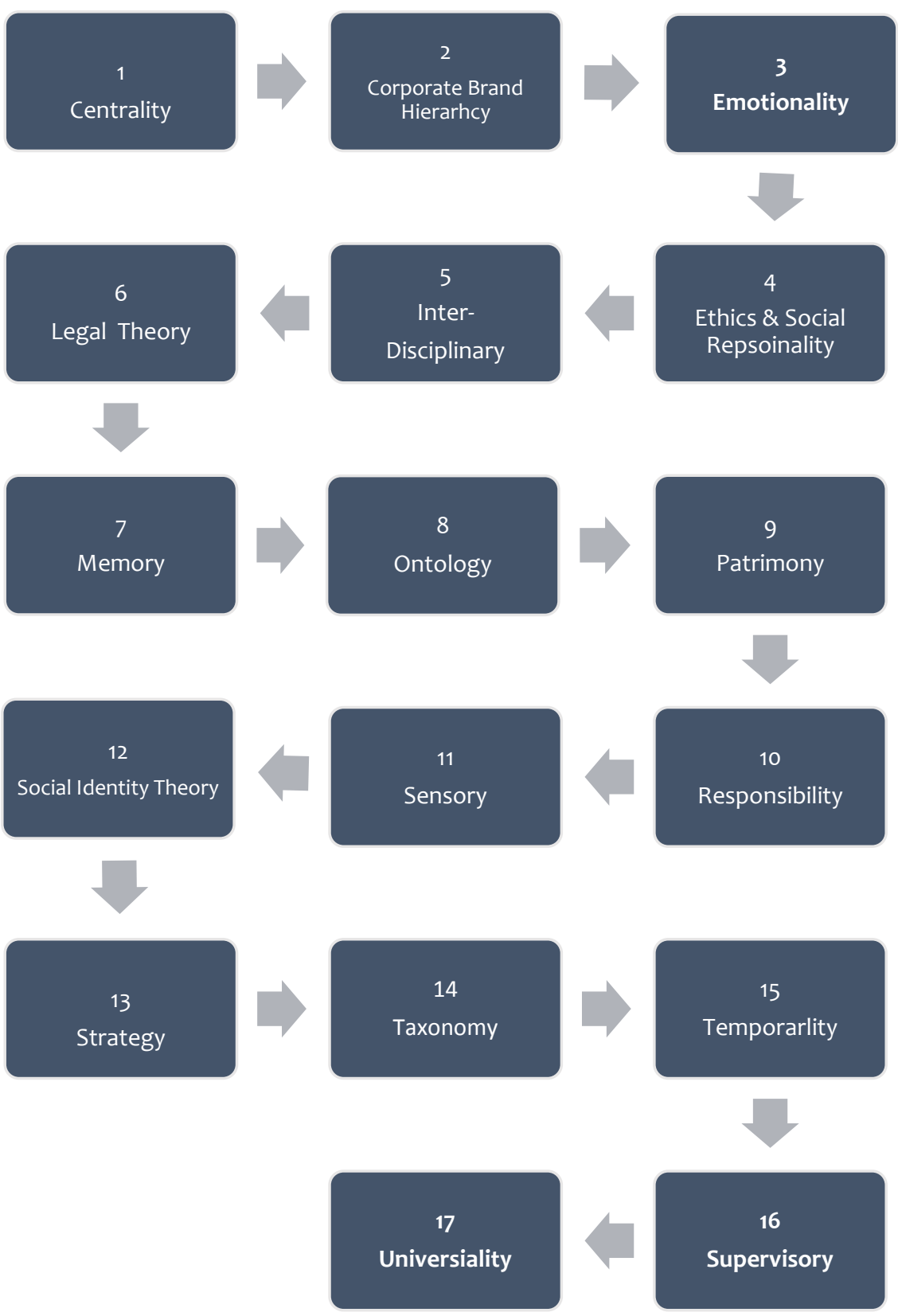

\section{Reflections on extant European Journal of Marketing Special Editions on the territory}

Unquestionably, the EJM has played a pivotal role in fostering scholarship in the above fields. In particular, it has an enviable provenance vis-à-vis the special editions devoted to the broad corporate marketing territory. 
Fig 3, shown below, details the special editions on the field. In their composite these special editions comprise rich streams of research and scholarly advances apropos corporate-level marketing concerns. The author has been privileged to serve as a guest editor/joint guest editor for some of the above. He also notes, with pleasure, how the other special editions have been guest edited not only by colleagues but by a former student of his too.

FIG 3: Extant special editions of the European Journal of Marketing focussing on corporate identity, corporate branding, and corporate marketing/organisational marketing.

\begin{tabular}{|c|c|c|}
\hline EJM: Special Edition Theme & $\begin{array}{l}\text { Date and } \\
\text { Volume and No }\end{array}$ & Guest Editors \\
\hline Corporate Identity & $\begin{array}{c}1997 \\
(\text { Vol. 31, No 5-6) }\end{array}$ & $\begin{array}{l}\text { Balmer J.M.T } \\
\text { and } \\
\text { Van Riel C.B.M. }\end{array}$ \\
\hline $\begin{array}{l}\text { Corporate identity and } \\
\text { corporate marketing }\end{array}$ & $\begin{array}{c}2001 \\
(\text { Vol. 35, No. 3-4) }\end{array}$ & Balmer, J.M.T. \\
\hline $\begin{array}{l}\text { Corporate marketing: } \\
\text { insights and integration drawn from } \\
\text { corporate branding, corporate identity, } \\
\text { corporate communication and } \\
\text { visual identification }\end{array}$ & $\begin{array}{c}2006 \\
\text { (Vol. 40, No. 7-8) }\end{array}$ & $\begin{array}{l}\text { Balmer, J.M.T., } \\
\text { Mukherjee, A., } \\
\text { Greyser, S.A. } \\
\text { and } \\
\text { Jenster. P. }\end{array}$ \\
\hline $\begin{array}{l}\text { Identity perspectives on } \\
\text { corporate and organisational marketing }\end{array}$ & $\begin{array}{c}2011 \\
\text { (Vol. 45, No. 9-10) }\end{array}$ & $\begin{array}{l}\text { Balmer, J.M.T. } \\
\text { and } \\
\text { Powell, S. }\end{array}$ \\
\hline Corporate branding & $\begin{array}{c}2012 \\
\text { (Vol. 46, No 5) }\end{array}$ & $\begin{array}{l}\text { Melewar, T.C. } \\
\text { Gotsi. M. } \\
\text { and } \\
\text { Andriopoulos. C. }\end{array}$ \\
\hline $\begin{array}{l}\text { Brand and corporate branding: } \\
\text { theory and emerging context }\end{array}$ & $\begin{array}{c}2012 \\
\text { (Vol. 46, No. 7-8) }\end{array}$ & $\begin{array}{l}\text { Abimbola, T. } \\
\text { Trueman, M. } \\
\text { and } \\
\text { Iglesias, } 0 .\end{array}$ \\
\hline $\begin{array}{l}\text { Advances in corporate brand, corporate } \\
\text { heritage, corporate identity and corporate } \\
\text { marketing scholarship. }\end{array}$ & $\begin{array}{c}2017 ? \\
\text { (Vol. ?. No.?) }\end{array}$ & Balmer, J.M.T \\
\hline
\end{tabular}

The EJM Symposium: Advances in corporate brand and corporate identity scholarship and the third marketing revolution.

The five articles constituting this symposium speak to the four celebratory events marked by this EJM symposium. As such, the five articles respectively focus on corporate identity, corporate marketing, corporate heritage, and corporate brands. A brief synopsis of the above are given below. 
the corporate identity, total corporate communications, stakeholders'
attributed identities, identifications and behaviours continuum.

Fittingly, the nuclei of the opening article focusses on corporate identity and on a schema which has corporate identity as its foundation. In this germinal and wide-ranging essay by John Balmer (Balmer, 2017) a new strategic framework is introduced (The corporate identity, total corporate communications, stakeholders' attributed identities, identifications and behaviours continuum). Balmer's article and resultant framework is informed by: (i) corporate marketing and strategic perspectives; (ii) the incorporation of the legal theory of the firm, social identity branch theories, and stakeholder theory; (iii) its discernment of corporate identity effects and management in terms of a continuum; and (iv) the accommodation of the early scholarship of Tagiuri. His article also gives guidance vis-à-vis corporate identity trait evaluation and offers new criteria for the prioritisation of stakeholders. Arguably, owing to the breadth of its ambitions along with its scholarly and instrumental foci, this essay has the potential to advance the corporate identity and corporate marketing fields.

\section{the transparency construct in corporate marketing.}

The second contribution to this symposium is by Professor Shirley Leitch: Dean and Professor, College of Business and Economics, The Australian National University, Canberra, Australia (Leitch, 2017). This article provides a valuable, and thoughtful, reflection apropos the transparency construct in corporate marketing. In Dean Leitch's estimation, a shared understanding of the transparency construct is a significant gap within corporate marketing theory. As such, this essay seeks to meaningfully address this gap. Professor Leitch's article includes a detailed definition of the transparency construct and deliberates on and particularises its saliency for corporate marketing scholarship and management. As always, the guest editor is highly appreciative of the important scholarly contributions emanating from leading Commonwealth Realms such as Australia.

Professor Leitch's article belongs to this category. Moreover, with its explicit focus on corporate marketing, Dean Leitch's article not provides a fitting - and thought-provoking - contribution to this celebratory EJM symposium.

corporate heritage brands, augmented role identity and customer satisfaction.

The third article is by John M.T. Balmer and Weifeng Chen. The article is notable for its focus on the Chinese Tong Ren Tang corporate brand (Balmer and Chen, 2017). Arguably, Tong Ren Tang is China's most celebrated and revered corporate heritage brand. The researchers found that the corporate brand's augmented role identitiesespecially its augmented imperial role identity were salient apropos customer satisfaction. The significance of this article resides not on its company and country foci and because it is one of the first corporate heritage studies focussing on consumers. The finding that Chinese consumers value the corporate brand's Imperial links and they regard Tong Ren Tang as having an enduring imperial patrimony is, in the authors' estimation, both extraordinary and revelatory in the light of the Middle Kingdom's recent history.

\section{corporate branding in perspective: a typology.}

Continuing the broad corporate branding theme, the third article by US scholar Professor Schroeder (who is a thought-leader in the general branding field) advocates the efficacy in adopting a new branding typology (Schroeder, 2017). From its formal 
introduction in 1995, the interdisciplinary nature of corporate brands has been stressed. In a similar vein, Professor Schroeder has noted how interdisciplinary perspectives increasingly inform brand scholarship. Mindful of the aforementioned developments and building on them, he introduces a new branding typology. In particular, the typology sheds light on the various ways corporate brands function. As such, Professor Schroeder's quadripartite branding typology comprises four "perspectives" namely: corporate perspectives, consumer perspectives, cultural perspectives and critical perspectives. The insights of his paper have real utility for corporate marketing scholars and others who are engaged in corporate brand scholarship. Unquestionably, Professor Schroeder's deliberations make a distinct and important contribution to the branding genre.

\section{leveraging the corporate brand: the importance of corporate brand innovativeness and brand architecture.}

The final article of this symposium is a Teutonic-American initiative and is coauthored article by the prominent German branding scholars Professor Tim Oliver Brexendorf and by the celebrated US branding authority Professor Kevin Lane Keller (Brexendorf and Keller, 2017). Notably, their article also has an explicit corporate brand focus. Their paper explores the transferability of corporate brand associations in relation to brand and product portfolios. Moreover, the authors deliberate on corporate brand innovativeness and brand architecture as supporters and restrictors vis-à-vis the transferability of corporate brand associations. Making reference to corporate marketing, Brexendorf and Aaker also note a corporate marketing perspective allows organisations to employ corporate brand associations in support of a firm's product and services. This article's breadth; its incorporation of the literature from both North America as well as Europe is indicative of the cross-fertilisation of scholarship in the corporate branding field and is testimony of the advances which have been made since 1995 apropos corporate brand scholarship. Moreover, it provides a fitting flourish to this celebratory symposium.

\section{Reflection}

Reflecting on the past twenty years, it is agreeable to reflect on the progress made in the broad corporate identity, corporate branding and corporate marketing fields. Increasingly, these areas have occupied a central place in corporate marketing scholarship and practice. Unquestionably, the EJM has played a pivotal role apropos the above.

Finally, and in a personal capacity, I also note how twenty years ago, 1997 marked three milestones in my own career and all linked to the EJM. These milestones are my first EJM article and my first EJM special edition and, unexpectedly, an invitation to join the editorial board. Clearly I and many other corporate marketing scholars owe EJM a huge gratitude of debt for helping to promote the field, develop the canon, and report theoretical and instrumental advances. Finally, it my hope, that this celebratory symposium will be in accord with the very best traditions of this journal.

Hopefully, twenty years on, many of the articles contained herein will be seen as cornerstone contributions in the annals of corporate identity, corporate brand, corporate 
heritage and corporate marketing scholarship. I might, just, still be alive to witness it. For now, it is enough to celebrate the progress made in the corporate marketing field. There is much to be grateful for and a good deal to celebrate. As for this celebratory EJM symposium: Read on and enjoy!

\section{Acknowledgements}

The Guest Editor wishes to thank the contributors for this special edition for penning insightful and thought-provoking articles. It has been an honour and a privilege to work with this most distinguished group of scholars. I also wish to express my sincere thanks to the EJM's Editor-inChief Professor Nick Lee (Professor of Marketing at Warwick University, UK) and to Richard Whitfield (Publishing Editor EJM) for their support, encouragement and patience apropos this special edition. In the same spirit I also wish to thank the former Co-Editors-in-Chief of the EJM with whom I worked on earlier special editions: Professor David Carson (Professor Emeritus of Marketing University of Ulster, UK) and Professor Audrey Gilmore (Professor of Marketing, University of Ulster, UK.). To all: "gratias vobis ago".

\section{References}

Balmer, J.M.T. (1995), "Corporate branding and connoisseurship”, Journal of General Management, Vol, No. pp.

Balmer, J.M.T. (1998), "Corporate identity and the advent of corporate marketing", Journal of Marketing Management, Vol, 14, No. 8. pp. 963-996.

Balmer, J.M.T. (2011) "Corporate marketing myopia and the inexorable rise of a corporate marketing logic: Perspectives from identity-based views of the firm", European Journal of Marketing, Vol. 45. Vol. 9-10, pp.1329-1352.

Balmer, J.M.T. (2017?) "Corporate marketing myopia and the inexorable rise of a corporate marketing logic: Perspectives from identity-based views of the firm", European Journal of Marketing, Vol. ?. Vol. ?, pp.?. (This Special Edition: Publisher to kindly enter details. Thank you)

Balmer, J.M.T. and Van Riel, C.B.M. (1997), "Special Edition on Corporate Identity". European Journal of Marketing, Vol. 31, No. 5-6. pp. 340-422

Balmer, J.M.T and Chen, WF. (2017?), "Corporate heritage brands, augmented role identity and customer satisfaction". European Journal of Marketing, Vol. ?. Vol. ?, pp.?. (This Special Edition: Publisher to kindly enter details. Thank you)

Balmer, J.M.T. and Greyser, S.A. (2006), "Corporate marketing: Integrating corporate identity, corporate branding, corporate communications, corporate image and corporate reputation", European Journal of Marketing, Vol. 40, No. 7-8, pp.730 - 741.

Balmer, J.M.T., Greyser, S.A. and Urde, S. (2006), "The Crown as a corporate brand: insights from monarchies. Journal of Brand Management, Vol. 14. No. 1 and 2, pp. 137161. 
Brexendorf, T.O. and Keller, K.L. (2017?), "Leveraging the corporate brand: the importance of corporate brand innovativeness and brand architecture". European Journal of Marketing, Vol.? No.? pp.? (This Special Edition: Publisher to kindly enter details. Thank you)

Leitch, S. (2017?), "The transparency construct in corporate marketing", European Journal of Marketing, Vol.? No.? pp.? (This Special Edition: Publisher to kindly enter details. Thank you)

Schroeder, J.E. (2107), "Corporate branding in perspective: a typology". European Journal of Marketing, Vol.? No.? pp.? (This Special Edition: Publisher to kindly enter details. Thank you)

Urde, M., Greyser, S. A., and Balmer, J. M. T. (2007), “Corporate brands with a heritage". Journal of Brand Management, Vol. 15. No. 1, pp. 4-19.

\section{About the author:}

John M.T. Balmer Took his PhD at Strathclyde University, Scotland in 1996, and within 3 years was elected Professor of Corporate Identity at Bradford University School of Management. He subsequently was conferred the title of Professor of Corporate Brand/Identity Management in the same University in recognition of his seminal scholarship on both territories. In a similar vein, in 2007, he was appointed Professor of Corporate Marketing at Brunel University Business School, London where he is Director of the Marketing and Corporate Brand Research Group. All three Professorial positions are understood to be the first appointments of their kind. Formally the introduced corporate brand construct; the corporate brand orientation concept the corporate marketing notion; the corporate heritage identity/corporate heritage marketing and monarchical marketing concepts. His work has been published in a number of leading journals including European Journal of Marketing, California Management Review, British Journal of Management, Journal of Business Research, Journal of Business Ethics, Long Range Planning, Industrial Marketing Management etc. 